\title{
COMMENTARY ON "USURY IN INSTALMENT SALES"*
}

\author{
STANLEX B. ECKER $\dagger$
}

Extensive comment upon the subject matter of Mr. Berger's thesis, due to the short period of time afforded for its review, has unfortunately been rendered impossible. This commentary will therefore be confined to the major points developed by Mr. Berger, and to a treatment directed primarily at the practical and factual, as distinguished from the purely legalistic, aspects of his treatise.

The Thesis Summarized: As the writer of this commentary understands it, Mr. Berger's thesis, briefly summarized, is as follows:

(I) Originally, usury laws were adopted to protect against exploitation, whether of borrower or buyer.

(2) In the Nineteenth Century, however, "the canonical notion that an excessive credit price was usurious was swept away by the rising tide of commercialism"1 and since that time the courts have excepted credit-sales from the operation of usury statutes-unanimously where a "lump credit price" has been fixed by the seller, and by a majority of courts where the seller has expressly reserved excessive interest on the cash price.

(3) Where the cash price is known and excessive interest is clearly reserved on a credit-sale, the courts should apply the usury statutes-following the existing minority rule-and

(4) Where the cash price is known "and it is obvious that excessive interest is reserved for the extension of credit, the transaction should be held usurious, though in the guise of a lump credit price."2

(5) If, by reason of decisional precedent, the courts cannot accomplish this result, or when this result has been achieved, the legislatures should then intervene to enact

\footnotetext{
- Enitor's Note: Galley proof of the preceding article, Usury in Instalment Sales, by Mr. Raoul Berger, was submitted to Mr. Ecker with a request for his comments. Unfortunately, the circumstances of publication were such as to afford Mr. Ecker only a limited period of time for review and comment, and Mr. Ecker's comment could not in turn be submitted to Mr. Berger.

Italics throughout are the writer's.

† A.B., I920, LL.B., I923, Harvard. Member of the Massachusetts and the New York Bars. Secretary and Assistant General Counsel of Commercial Investment Trust Corporation.

${ }^{2}$ See sentence following footnote 52 of Mr. Berger's article, Usury in Instalment Sales, supra p. 148 , at p. 156 .

"See "Conclusion" of Mr. Berger's article, pp. 170-172.
} 
legislation for the "protection" of the consumer because (a) the distinction between credit sales and loans rests "on a slender historical and legal base,"3 (b) the "solution worked out by the majority of courts in seeking to facilitate credit sales has in many instances been as pernicious, from the viewpoint of one needing credit, as was the once complete repeal in England of all restrictions on loans"; (c) the need for protecting the instalment buyer against "exploitation" is as urgent as it is in the case of the necessitous borrower.

The Historical Background and Legal Precedents: We have no quarrel with Mr. Berger on the development of the historical background which he has traced back to Biblical days, nor with his exposition of the English and American precedents relating to usury laws. Although not in entire agreement with all of Mr. Berger's statutory and decisional analyses, we are quite willing for the purpose of this commentary to accept their validity. We are emphatically unwilling, however, to concede the validity of the argument and conclusions which Mr. Berger has proceeded to erect on the foundation of his historical development and on the premise of his decisional and "social and economic" analyses.

The Significance of the Judictal Precedents: The judicial exclusion of credit sales from the operation of usury laws-which Mr. Berger characterizes as "one of the phenomena resulting from the bias of courts against usury legislation"-had its initiation in the Common Law in the case of Beete v. Bidgood ${ }^{0}$ (decided in I82I), according to Mr. Berger, who, commenting on this decision, says: "Possibly the canonical notion that an excessive credit price was usurious was swept away by the rising tide of commercialism." If the word "possibly" had been omitted from this comment; if the significance of the statement, minus the "possibly," had been fully realized and then applied by the author to the facts of instalment selling and instalment-sales financing as they exist today, it is this commentator's belief that the tone and substance of Mr. Berger's treatise would have been completely changed-and the conscientious reader of this journal spared the labor of scanning this commentary.

The fact of the matter is that the court in the case of Beete v. Bidgood was influenced-and properly so-by the "rising tide of commercialism" to cast aside the "canonical notion" that a bona fide sale on terms of a deferred payment of the sales price is in the same category as a loan; and that the court was cognizant of the necessity, in a commercial as distinguished from a "canonical" world, of freeing commercial transactions which depend on the extension of credit from the dangers of forfeiture and penalty. And it is significant to note, as Mr. Berger points out, that the courts, both English and American, have, since Beete v. Bidgood, with complete unanimity followed its precedent. Whether or not the wisdom of the judicial adherence to the doctrine of Beete v. Bidgood has been vindicated-viewed from the

Ibid.

'Ibid.

${ }^{5}$ Sec sentence following footnote 8 of Mr. Berger's article, p. I 49.

-Footnotes 52 and 106 of Mr. Berger's article, Pp. 156, 165.

TSee note I, supra. 
social and economic standpoint, is a question to be answered later in this commentary.

Analysis of the Instalment Sale: At the portals of his treatise Mr. Berger has posed, for the reader's inspection, a hypothetical Mr. "A," and three hypothetical transactions upon which Mr. " $A$ " is thereupon embarked: (I) In Transaction One Mr. "A" borrows money and pays cash for some furniture. (2) In Transaction Two Mr. "A" buys the furniture on what Mr. Berger terms "the instalment plan" at a credit price "determined by adding the interest in a lump sum to the cash price." (3) In Transaction Three Mr. "A" also buys "on the instalment plan," obligating himself, however, "to pay the seller the cash price, at an interest rate expressed as such."

Transaction One is of course a loan. Transaction Two Mr. Berger would treat as a loan. And Transaction Three he would, via the route of judicial decision or legislative act, treat in the same way as Two. And if the "interest," whether separately reserved as in Transaction Three, or "lumped" in the credit price, as in Transaction Two, exceeds the legal rate of interest for a loan, Mr. Berger would brand these sales with the stamp of usury, and subject to the forfeiture and penalties imposed by the usury statutes, the vendor's rights against the buyer.

Let us stop for a moment to analyze Mr. Berger's hypothetical Transactions Two and Three, with a view to ascertaining which, if either, represents the modern credit sale. The typical credit sale of today is a sale on the instalment plan and it is of course on the instalment sale that Mr. Berger has centered his entire thesis. It is common knowledge that,-whether or not he intends to dispose of the paper created in connection with the instalment sale to a separate financing corporation,- the instalment seller does not require the buyer "to obligate himself to pay the seller the cash price, at an interest rate expressed as such."8 Accordingly, we may dismiss from our consideration as having only academic interest the hypothetical transaction numbered "Three,"--and proceed to Transaction Two.

Transaction Two, we will remember, is the case stated by Mr. Berger as a sale "on the instalment plan" at a credit price "determined by adding interest in a lump sum to the cash price." We start off then with the cash price, which is presumably a known factor. We then add "the interest in a lump sum,"- and that, Mr. Berger would evidently have us believe, is a typical instalment sale. Of course it isn't-for the simple reason that the amount which is added by the instalment seller to the cash price isn't "interest" at all.

In determining the cash selling price of any commodity every merchant takes into account the cost to him of the commodity and the cost to him of consummating the sale,-which means all costs incurred by him up to the time when he receives payment from the buyer, and even beyond that time, in cases where the seller may be called upon to "service" the commodity which he has sold. If services must be

"See first paragraph of Mr. Berger's article, p. I48. 'Ibid. 
rendered and expense incurred, the cost of such services and the amount of such expenses are added by the merchant in determining the price at which he will sell. And if the sale is to be made on a "charge account" basis, or on the basis of a sale subject to a discount if paid within a certain period of time, the vendor will also take into account, in determining his selling price, the cost to him involved in deferring receipt of payment for the commodity he has sold. To the writer's knowledge, no one has ever advanced the proposition that any one of these elements which commonly go to make up the selling price of goods should be labeled "interest"; and no reasonable person would. Yet, where the sale-on-credit is payable in instalments, by some mysterious evolution these elements become transformed in Mr. Berger's mind into "interest," with the result that the instalment seller is set apart from his more fortunate brethren, the vendor-for-cash and the vendor on the charge account or "discount" basis, and forced to justify the price at which he has sold "on credit" by application of the measuring stick of a usury statute!

The exposition of the "Historical Background" of usury laws contained in Mr. Berger's treatise is of more than academic interest when examined in connection with the foregoing discussion. Reduced to a few words the historical essence amounts to this: "Interest," from Biblical days to date, has always been a term employed to describe the measuring stick for monetary compensation for forbearance; and where parties to an agreement express, or the facts of a transaction evidence, a clear intention that the compensation to be paid by the one to the other is to be a compensation reserved solely as consideration for forbearance, there is validity to the argument that the "interest" measuring stick should be applied and that the transaction should accordingly fall within the purview of laws relating to "interest." But where no such intention is expressed and where, as in the case of a bona fide credit sale, the compensation to be paid is not in consideration of forbearance alone, but of the costs and expenses which must necessarily be incurred by the seller before consummation of the sale and payment to him of the purchase price, there can be no validity to any argument which would place the instalment seller in any different position, economic or legal, than the seller for cash.

What then are the factual elements inherent in the modern instalment sale? Is there any essential difference between the elements taken into account by the seller in determining the time-selling price and the factors, mentioned above, which other sellers take into account in fixing the price which they are willing to accept for their wares? The seller "on credit," as in the case of other sellers, knows that both prior and subsequent to delivery of the goods to the buyer, he will have to incur various items of expense, before receipt of the full purchase price and final consummation of the transaction; and, like the seller for cash, he must take account of these items in determining his selling-price. The expense of investigating the credit of the prospective purchaser must be incurred before the sale is approved; if the credit is acceptable and the sale made, the account must be set up on the books of the seller 
and thereafter each week or month, depending upon the terms of payment, the purchaser must be notified of the maturity of his instalment and collection effected of the instalments as they mature until full payment of the purchase price has been made. Should the buyer be "slow" in making his payments or should default occur, the expense of collection is of course increased and may include the fees of attorneys and the costs of court proceedings. Frequently, and, in the case of motor vehicles, customarily, insurance ${ }^{10}$ must be purchased to protect the time-seller's interest in the chattel, which of course constitutes another element of expense which must be taken into account by the time-seller in determining the time-selling price. This item of "overhead" as a matter of fact is also one which is incurred by the cash-seller, but of course in the case of a cash sale the coverage and therefore the expense of the insurance is limited to the period prior to delivery of the goods to the buyer.

As in the case of the charge-account sale and the sale at a "discount" (which is deductible from the purchase price if the account is paid within a stipulated period), the merchant who sells on the instalment plan must also take into consideration the fact that while any balance is outstanding and unpaid on the purchase price, he is deprived, pro tanto, of the use of the funds which, had full payment been made by the buyer in cash on delivery, he would have been able to utilize immediately in his business. This factor is of course an important one from the viewpoint of the instalment seller, as it is in the case of other sellers who do not receive payment in cash of the full purchase price on delivery of the goods. It is an element, as is the risk of credit losses, which must necessarily be considered in the determination of the selling price but it is only one of the various elements, mentioned above, which are determinative of the amount at which the time-seller may be willing to dispose of his goods. On Mr. Berger's premise and the clear implication of his argument, this element, which he terms and would treat as "interest," is the only one which enters into the computation of the credit price. This premise being erroneous, Mr. Berger's entire argument falls, and with it, the conclusions which he has erected thereon.

It might be contended by Mr. Berger, in support of the analogy which he seeks to draw between an instalment sale and a loan of money, that the elements adverted to above which the seller takes into account in fixing the credit price of his merchandise are the same and are given the same consideration as those which the lender of money takes into account in determining the interest charge for the so-called "small loan." The distinction, from an economic point of view, between a credit sale and a loan is considered later in this Commentary; two distinguishing factors might, however, be mentioned at this point. The first is inherent in the fact that the seller on time is motivated and restrained, in determining the charge to be made for the time-sale, by commercial and competitive considerations, which do not influence to the same extent, if they influence at all, the lender of money. The other,

\footnotetext{
${ }^{10}$ See Adelson, The Mechanics of the Instalment Credit Sale, infra, p. 218, particulariy the section cntitled "Insecurity and Insurance Provisions," p. 231, and statements preceding and following the reference to footnote 18 in his article, p. 222.
} 
a material factor in fixing the time-price, relates to the dollar-amount to be charged the buyer for the use of the goods sold, and involves a determination of the variable of depreciation and the effect of the buyer's use of the goods on the resale value in the event of their return to the seller. This factor is of course non-existent in the case of the small loan which is made on the strength of one or more endorsements, and, in the case of other small loans, which are for the most part secured by the household goods of the borrower, is of relatively little importance, because the value of the collateral in the latter type of loan lies in what might be termed the "deprivation value" inherent in the threat of foreclosure rather than in the value of resale, the criterion of the vast majority of time-sales.

The factual elements in the instalment sale, briefly outlined above, are today so well known that it would be surplusage to cite authorities in proof of their existence. That the courts, cognizant of these elements, have uniformly and unanimously refused to deprive the instalment seller of the right to determine, as does the seller for cash, the price at which he may sell, is admitted by Mr. Berger ${ }^{11}$ who has referred to some of the cases. Express support for this analysis is to be found in judicial opinions. ${ }^{12}$

The Status and Function of the Finance Company in Instalment Seling: The legal status of the finance company as the assignee of the instalment contract, and the general method of operations of sales finance companies are, I understand, to be made the subject of complete exposition elsewhere in this issue. Briefly, the part played by the finance company in financing consumption is as follows: ${ }^{13}$ (I) The finance company makes the credit investigation of the purchaser; (2) if the transaction is acceptable to the finance company, the instalment contract is purchased from the seller of the goods; (3) after the contract has been purchased the finance company, as assignee, performs the collection services which otherwise would have to be performed by the seller. All of the cost and expense, (including the cost of insurancecoverage of the commodity), and all of the risk, except to the extent of the protection afforded by the recourse (which is usually a limited recourse) against the seller, which

\footnotetext{
${ }^{11}$ See first paragraph of Mr. Berger's article.

${ }^{21}$ See Comm. Credit Co. v. Tarwater, 215 Ala. I23, I10 So. 39 (1926): "The dealer had the perfect legal right to dispose of the property on such terms as agreed upon, one price for cash and another price if sold on credit. . . . there are elements of risk, trouble, and expense incident to such transactions, which are to be taken into account, but of whatever items it may be composed, if in fact the sum agreed upon represents in good faith the credit price of the car as understood by the parties, the transaction is free from any taint of usury." See also In re Bibbey, 9 F. (2d) 944 (D. Minn.): "There is no question but what the seller may name a greater price when he sells upon time than when he sells for cash, and that is not an unusual practice and custom in merchandising. Of course, in calculating the amount of addition to the cash price, where the goods were sold upon time, what would be a proper interest upon the investment is taken into consideration; the chances of loss and failure to pay, and the insurance necessary to cover the transaction, and the overhead expense for carrying on a business of that kind, all find a place in ascertaining how a merchant may profitably sell upon time and the price to be charged; but this does not make a usurious contract."

${ }^{12}$ Mr. Adelson's article, The Mechanies of the Instalment Credit Sale, infra, at p. 219, presents an excellent exposition on this subject. See also Cavers, The Consumer's Stake in the Finance Company Code Controversy, infro, p. 200, particularly the introductory paragraphs and the section entitled "The Or. ganization of the Industry," p. $20 x$.
} 
the latter takes into account in determining the time-price, are assumed by the finance company. Based on its knowledge of the cost and expense and the risk elements which enter into the instalment sale, and its specialized experience in the field of consumer credit, the sales finance company establishes the price at which it will acquire paper from the instalment-seller. This is done in the field of automobile sales financing through the medium of what are commonly termed "rate charts" furnished by the finance company to the seller so that he may know, before consummating the sale, the price at which he will be able to dispose of the instalment contract arising therefrom. Ordinarily, the instalment-seller, in determining the price at which he will sell "on credit,"--and this is especially true in the case of sales of automobiles,-will add to the cash price the dollar and cent amount of the differential shown in the finance company's rate chart. If this is done and the sale of the paper to the finance company is completed, the seller will have received in cash the amount which he would have received had the buyer purchased for cash rather than "on time." It should be emphasized at this point that until the instalment contract has been purchased the finance company has no contact which the instalment buyer, except as might be made necessary by reason of the credit-investigation service performed by the finance company, and that except to the extent that the seller may be influenced by the price which the finance company has indicated it will pay for the paper, the finance company plays no direct part in establishing the price at which the time sale may be made.

The function of the sales finance company and the importance of its role in our present day industrial system cannot be understood unless cognizance is taken of the close relationship which exists between the manufacturer and distributor of commodities ordinarily sold "on credit" and the financing corporations. This relationship, as is true in the case of at least one of the so-called national finance companies, may be cemented by capital stock ownership; it may exist by virtue of contractual arrangements pursuant to which the services of the financing company may be recommended by the manufacturer; or it may exist without stock ownership and without any contractual arrangements between the manufacturer and the financing corporation.

The major aims of the manufacturer in these days of mass production are ( $I$ ) to maintain as low as possible the cost of production and (2) to maintain as low as possible the cost to the consumer. Increased volume of sales of course aids in the accomplishment of these aims, and instalment selling has proved to be an effective means of increasing sales volume. ${ }^{14}$ However, unless the manufacturer and the merchant are able to meet the sharp competition prevalent in modern merchandising by maintaining a low cost to the consumer, increased volume and enhanced profit to the manufacturer and to the merchant will not be obtainable. It is a fact, therefore, that the manufacturer and the merchant are ever on the alert to maintain low

"See quotation from the Report to the Wisconsin Legislature of the State Banking Committee and Interim Advisory Legislative Committee, infra, p. 18r. 
financing charges, and because of the benefits which are derived from a satisfactory relationship with manufacturers and merchants, the sales finance company has in the past always been, and it may with certainty be expected will in the future continue to be, actively responsive to factory and distributor pressure to maintain as low as possible the level of financing charges. It is apparent, then, that the operations of sales finance companies are substantially affected by the manufacturing and merchandising problems of the seller of goods, and that Mr. Berger's argument, which links the instalment sale with a loan on the ground that the "motives" actuating the activities of separate financing corporations are "not distinguishable from those of a lender," ${ }^{15}$ is built upon a false premise of fact and is therefore untenable.

At one point in the course of his treatise Mr. Berger seeks to create the impression ${ }^{16}$ that the cost to the consumer of instalment credit has increased and that increased volume of instalment-sales and instalment-sales financing have not brought about any decrease in the consumer-cost. In refutation of this, the following statistics, taken from published rate charts of the company with which the writer is associated, are significant: (It is reasonable to assume, due to the highly competitive conditions existing in the field of consumer-financing, that these statistics are typical of the general trend of sales-financing rates.) The volume of business of this company, in the year 1932, was substantially less than the volume of business for the comparable period in the current year. However, the consumer-cost of financing the purchase of three standard makes of motor vehicles (after adjustment of the $193^{2}$ finance rates so as to reflect the inclusion of collision-insurance coverage equivalent to that included in the 1935 finance rates) shows a decrease in the average of 19.02 per cent in one of the territories in which the operations of this company-are conducted, 16.47 per cent in another territory and 8.62 in a third territorial division. The foregoing statistics are based on financing rates applicable to instalment purchases in three widely divergent territories in the United States.

In this connection, Mr. Berger seems to contend that the profits earned by "separate financing corporations" have been inordinate. ${ }^{17}$ It is correct that the operations of the so-called national finance companies have been profitable over a period of years. It is denied however that the profits earned by these companies, on a comparative basis with the profits of representative groups of industrial, utility, and railroad corporations, have been excessive. From the standpoint of the consumer the measuring-stick to be applied to the profits of a finance company is the profitreturn to the finance company based on the amount of funds, whether derived from capital or other sources, placed at the disposal of the consumer through the mechanics of financing his instalment paper. The proper test, therefore, must necessarily be a comparison of the amount earned by finance companies in relation to the total assets from which these earnings are derived, with the amount earned by other

\footnotetext{
${ }^{15}$ See the last sentence but one preceding Mr. Berger's section entitled "Historical Background, p. 153.

${ }^{10}$ See statement in Mr. Berger's article which precedes his footnote 35, p. 154 .

rIbid.
} 
businesses in relation to the total assets employed by them. Standard Trade and Securities-Bulletin of July 13 , I934, publishes the earnings and balance sheets of 418 industrial corporations representing the leading organizations in the country; also, of 22 leading public utilities and 25 large railroads. The industrial group averaged during the years 1927-33 inclusive 5.II per cent of net income to their total assets; the public utilities for the same period averaged 3.28 per cent and the railroads for the same period averaged 4.35 per cent. We find, however, from an analysis of data contained in Moody's Manual of Investments that the three leading finance companies which handle a majority of the financing in the consumer credit field averaged only 3.25 per cent of net income as compared with the assets employed by them during this same period.

The Social and Economic Factors: The failure of Mr. Berger to appreciate the close relationship between the sales finance company and the manufacturer and distributor of consumer-goods, and the influence of this relationship upon the "motives" of separate financing corporations, accounts in large measure for the recommendations outlined in the "Conclusions" to his article (summarized as Item 5, in the opening paragraph of this Commentary). It is also apparent, however, that Mr. Berger's views on what he terms the "social and economic factors" inherent in the field of consumer credit and consumer credit financing have unfortunately been colored by other factual misapprehensions chief among which are the following:

(I) ". . . Pernicious from the viewpoint of one needing credit . ..," according to Mr. Berger, has been the result "in many cases" of the refusal of courts to bring credit sales within the purview of usury statutes. ${ }^{18}$ That the result has been the opposite of "pernicious" is pointed out in the Preface to the Report of the State Banking Commission and Interim Advisory Legislative Committee recently submitted to the Wisconsin Legislature. ${ }^{19}$ The following language taken from the Report is worthy of quotation:

"Therefore, it should be borne in mind in considering the reasonableness of consumer credit charges that the production, distribution and sale of articles in installments was only made possible for the mass of consumers because of adequate mass financing. This mass financing has brought within reach of the average individual a wealth of articles which were never thought of in previous years, has raised the standard of living of the common people, and has reduced the price of thousands of articles until they are within the reach of the average individual. Prior to the evolution of mass finance, an ordinary automobile cost approximately three times as much as it does today and this holds true with many other articles which are now considered in the realm of necessities for the average family.

"The automobile finance and loan companies are a recent development, practically within the past thirty years. As before stated, due to this rapid growth it is only natural that abuses have crept in. The Committee, however, has been agreeably surprised to find that a large portion of this business is handled upon a rather high plane, and with the

\footnotetext{
209 See note 2, supra.

${ }^{10}$ This is the Report to which Mr. Berger refers in his footnote 130, p. 170.
} 
elimination of certain abuses as herein pointed out, the Committee feels certain the consumer will not have much cause for complaint.

"Consumer credit is a highly specialized business, which requires special organization and highly specialized methods of operation. This has been generally recognized, particularly by commercial banking institutions who consider consumer credit companies among their best risks. The finance companies of the United States are today probably the largest borrowers from the commercial banking system, second only to investments made in United States Government bonds.

"It is conceded that the automobile industry has come through a great depression employing thousands of people at substantial wages and without increasing the price of their product. This industry might well have been prostrated during the depression in the same manner as hundreds of other industries, were it not for the fact that dealers and purchasers of automobiles have been at all times adequately financed. Had consumer credit in this line not been available, the automobile and other merchandise sales would have been paralyzed, additional thousands would have been thrown out of work and the prices of merchandise would have materially increased to a point out of reach of the average consumer."

(2) "Glaring credit abuses"-according to Mr. Berger-abound in the field of consumer credit. As authority for his statement Mr. Berger refers to the report of the Indiana Department of Financial Institutions which in turn quotes from the report of an investigation by the Pollak Foundation for Economic Research. Examination of this report shows isolated examples of high finance charges for the most part in connection with the sale of commodities having no standardized cash price. Although Mr. Berger admits that "the standard high-grade finance companies' rates on long term contracts are considerably lower," 20 he does not point out that most of the dollar volume of instalment-sales financing is handled by these companies. ${ }^{21}$ That rate "abuses" affect only a small percentage of the total volume of consumer credit has been recognized in the Report of the Wisconsin Banking Commission and Interim Advisory Legislative Committee, which emphasizes the fact ${ }^{22}$ that in the State of Wisconsin about 15 per cent of those engaged in the automobile finance business and the selling of automobilés on time payments are responsible for 95 per cent of the abuses to which reference is made in the Report; ${ }^{23}$ it is also significant that the Report of the Wisconsin Committee, by its own terms was "not directed against the eighty-five per cent of individuals who are carrying on said lines of business in a legitimate and ethical manner, and who handle at least ninety per cent of the total volume of business." It is reasonable to assume that where abuses exist in the field of consumer financing-in states other than Wisconsin,-the percentage of dollar-amount of transactions affected is similarly insignificant.

\footnotetext{
${ }^{\infty}$ See Mr. Berger's footnote 17, p. 150.

"On this point, see Cavers, The Consumer's Stake in the Finance Company Code Controversy, infra, at p. 201.

At p. 4.

The Committee qualified its statement by exeepting practices with respect to "reserves, rebates and pack abuses and concealment of rates." A discussion of these subjects appears in Cavers, The Consumer's Stake in the Finance Company Code Controversy, supra note Ig.
} 
(3) At various points in his treatise ${ }^{24} \mathrm{Mr}$. Berger refers to concealment and "obscurity" of actual credit costs, particularly through "such devices as the lump sum credit price." All of this indicates Mr. Berger's belief to be that the instalment buyer is generally deceived as to the cost to him of buying "on credit" with the result that his "bargaining position" is thereby "impaired."

Now, what are the facts? With the exception of a few such articles as jewelry, furniture and clothing, the instalment sales of which amount only to a small fraction of the total dollar-amount of credit sales, practically every commodity which is generally sold on credit has a standard or at least a readily ascertainable cash selling-price and is sold in a highly competitive retail market. That being so, the opportunity for concealment and "deception" in the case of an instalment sale is no greater than in the case of a cash sale. The prospective instalment buyer can "shop" for the proper time price, as he can for the proper cash price, and his "bargaining position" is accordingly left entirely unimpaired. Furthermore,-and this is particularly true in the case of automobiles, refrigerators and oil burners-the contract forms used by the sellers frequently show on their face, in itemized form, the cash price together with the dollar amount of the financing charge. In this connection it is interesting to note the program initiated by one of the national sales finance companies to instruct the instalment buyer, through an extensive advertising campaign, as to the various elements entering into the time price of an automobile. These advertisements point out how the time buyer may check and compare costs in time payment plans, by enumerating in chart-form, the items of down payment and total monthly payments, from the sum-total of which the cash price, also enumerated, is deducted to show the resulting cost of financing and insurance.

Mr. Berger refers ${ }^{26}$ in his article to the recommendation of the Consumers Advisory Board that the statement of the finance charge be shown in the instalment contract both as a money charge and "as a rate per month on the unpaid balance of the contract." Mr. Berger comments on the "indignant protest by the finance companies" to this suggestion-and a moment's consideration of the question shows the justification for the protest. The requirement that the instalment seller state the finance charge in terms of interest, to start with, induces a misrepresentation of the facts to the buyer, because it is based on the false premise that the finance charges represent "interest." Furthermore, the statement that the finance charge is equivalent to interest at a certain per cent per month on descending unpaid balances owing on the contract of purchase would mean little or nothing to the man who buys on time. The ability of the instalment buyer to pay for the commodity which he has purchased "on credit" depends upon a careful budgeting of his income and of his required expenditures, and it is apparent that the information conveyed by such a statement would be of no aid to the buyer in determining the make-up of his budget. If you tell a prospective

\footnotetext{
"See particularly Mr. Berger's discussion in the third paragraph of his section on "Social and Economic Factors," p. I5I.

${ }^{25}$ See Mr. Berger's footnote 23, p. 152.
} 
time buyer that the cost to him of buying an automobile on a twelve monthly payment plan rather than for cash would amount to $\$ 60$ more than the cash price, he will know that $\$ 5$ per month more will have to be available than if he had accumulated his savings and then purchased for cash. If, in addition, you tell this buyer that the $\$ 60$ is equivalent to a stated per cent per month on the descending unpaid balance of the purchase price, you add nothing useful to his fund of informationand will probably have accomplished no more than to confuse him. Further-to make this requirement effective would unquestionably result in increasing the financing cost to the consumer-because of the mechanical burden and consequent expense factor imposed upon the seller of computing in the case of each transaction, the cost of the credit, transposed mathematically into terms of "interest" on each monthly unpaid balance of the purchase price. The recommendation of the Consumers Advisory Board that the statement of the finance charge be shown in terms of interest as a rate per month on descending unpaid balances was incorporated in several bills introduced in various state legislatures during the current legislative sessions. It is significant that without exception the legislative bodies in these states rejected the recommendation.

(4) At various points in his treatise Mr. Berger takes the position that there is no real distinction, from an economic point of view, between a credit sale and a loan ${ }^{20}$ and that the purchaser on credit is for all practical purposes in the same category as the necessitous borrower, for whose protection the usury statutes were enacted. In the case of this type of borrower it is his "necessities" which require the procuring of a loan of money. His credit is low, or non-existent; his needs are great; he is not a free agent. He must be protected from unscrupulous and exacting lenders whose sole motive is to capitalize on his needy situation. In the case of the purchaser of property on credit the situation is entirely different. $\mathrm{He}$ is moved by desire and not by necessity. He is a free agent in a competitive market. He can shop; he can make comparisons of goods and of financing charges; he can take his time and he can wholly refrain from purchasing. His volition is uncontrolled. Furthermore, as has been pointed out above, he is protected, where the borrower is not, by the free and active forces of competition as between manufacturers and distributors of the goods of which he is a potential purchaser, plus the equally active competition between those engaged in the business of financing consumer-credit. ${ }^{27}$

Conclusions: At the beginning of this Commentary the writer stated his understanding of Mr. Berger's thesis to be as follows: Credit sales should, if possible, be held by the courts to be within the purview of existing usury statutes, and, whether such decisions are reached or not, the legislature should intervene to solve "the

${ }^{20}$ See Mr. Berger's statements referred to in his footnotes 31 and 32, p. 153 .

"As stated by the State Banking Commission and Interim Advisory Legislative Committee in its Report to the Wisconsin Legislature (1935) at p. 60: "Therefore the Committee feels that the keen competition between automobile finance companies who are interested in time payment purchases will, when the public has full knowledge of all charges including reserves, rebates and 'packs,' reduce installment credit rates and charges to the lowest possible point." 
problem of creditsales." In the comments appearing above the writer has attempted to point out the factual fallacies underlying Mr. Berger's conclusions. The fallacies of Mr. Berger's conclusions, however, may perhaps best be disclosed by adverting briefly to the consequences which would follow if Mr. Berger's views were accepted by the courts.

Usury statutes generally fix a maximum per annum rate of interest of 6 per cent or in the neighborhood of that figure. Accepting for the moment Mr. Berger's premise that the so-called finance charge should be treated as "interest," it would follow, if Mr. Berger's recommendations had had the force of law, that every instalment sale in connection with which the credit charge amounted to more than 6 per cent per annum would have been subject to the forfeiture and penalty provisions encompassed in usury statutes. It is universally recognized that consumer credit cannot be extended at the usual commercial borrowing rates of "interest." 28 It is apparent, therefore, that if the courts had accepted Mr. Berger's thesis and refused to follow the precedent of Beete v. Bidgood in exempting bona fide credit sale transactions from the operation of usury statutes, all of the many recognized benefits directly attributable to the growth of consumer credit would have been lost-to the detriment of the so-called "forgotten man" as well as to the industrial community as a whole.

Although the writer understands that Mr. Berger disclaims advocacy of any specific legislative remedies, it appears from a reading of his article that he would recommend some kind of legislative intervention in order to "protect" the consumer body. As already indicated in this Commentary, issue is taken with Mr. Berger on the question of the need for protection. It seems to the writer that Mr. Berger's views have been influenced, and, with due regard for the conscientious motives which have undoubtedly inspired Mr. Berger's efforts, distorted by undue emphasis on isolated cases of abusive practice, gleaned from reports of investigating committees whose tendency, as is generally true of investigating bodies, has been to over-emphasize the existence of the abuses being investigated. That abusive practices exist in the field of consumer credit, as they do in every phase of all business and economic life, is not denied. There have undoubtedly been many cases in which the instalment purchaser has been deceived and even defrauded. But remedies for fraud and deception exist in the law today, apart from usury statutes, and the remedies afforded by existing laws require no further implementing to give "protection" to the victims of fraud and deceit. Even more effective, moreover, is the two-fold influence of the competitive forces which exist, in the first instance, in the field of manufacturing and merchandising of consumer goods and, in the second, in the field which extends facilities for financing consumer credit. The major companies operating in the latter

\footnotetext{
${ }^{28}$ As stated in the Report to the Wisconsin Legislature, supra note 27, at p. 50: "However, it must be taken into consideration that cash and merchandise credit cannot be handled under regular commercial bank rates of interest. . . . It should be further realized that a small item of consumer credit entails as much detail as a large extension of credit in a bank. There are investigations, reports, follow-up correspondence, and a multitude of things necessary to furnish this service. There is much less overhead of this kind in regular commercial banking. . .."
} 
field, whether or not directly affliated with manufacturers of the products whose sales they finance, are corporations equipped with substantial capital, are competently managed and conduct their business under high standards. They are today very large borrowers from the commercial banking system and, having at stake a substantial investment in the instalment financing field, it is reasonable to expect that they will exert every influence to eliminate such abusive practices as are bound to arise in an industry which has grown as rapidly as the business of instalment financing. ${ }^{20}$

If the legislative intervention which Mr. Berger has urged were to go so far as to subject the determination of credit prices to regulation by statute, it is submitted that it would then be invading even more dangerous ground. As has been pointed out in this Commentary, the essential elements entering into the determination of the time price of a commodity are no different from those elements which are inherent in the determination of cash price. It has ever been a primary rule of our economic system that the fixing of prices is a function in which government should not interfere; it has also been a cardinal principle of our constitutional government that the right of an owner to fix the price for which his property may be sold is an inherent property right and as such protected under the due process clause of the Fourteenth Amendment. ${ }^{30}$ Whether the differential between the cash price of a commodity and the price at which it is sold on credit be termed "interest" or labeled with any other designation, in the last analysis the determination of the amount of this differential resolves itself into a question of merchandising "mark-up." The storekeeper who buys his merchandise on sixty days credit with a privilege of paying in ten days at a discount of 6 per cent of the amount of the purchase invoice saves $\$ 6$ by anticipating fifty days on a $\$ 100$ debt for merchandise. This is equivalent to interest at the rate of over 43 per cent per annum, but no one would seriously advocate the application of usury laws or regulatory legislation to such a transaction. This example only emphasizes how unsound would be the result if, by legislation, the buyer's discount

Even such proponents of regulation as Messrs. Nugent and Henderson, whose various writings on the subject have been cited as authority by Mr. Berger, have admitted that "the major part of instalment selling and instalment financing is highly reputable." See Pollak Pamphlet 30, by L. R. Foster, Associate Director of the Pollak Foundation for Economic Research.

${ }^{20}$ It has repeatedly been held by the United States Supreme Court and other courts that the right of an owner to fix the price for which his property will be sold is an inherent property right and as such is within the due process clause of the Fourteenth Amendment. Wolff Packing $C_{0}$. v. Court of Industrial Relations, 262 U. S. 522 (1923); Chesapeake \& Potomac Telephone Co. v. Manning, 186 U. S. 238, 246.7 (1902); Tyson \& Bro. v. Banton, 273 U. S. 4I8, 430 et seq. (1927); Ribnik v. McBride, 277 U. S. 350 (1928).

In Tyson \& Bro. v. Banton, supra, at 438, the Supreme Court said: "Nor is the sale of ordinary commodities of trade affected with a public interest so as to justify legislative price fixing. This court said in Chas. Wolff Packing Co. v. Court of Industrial Relations, siipra, p. 537: 'It has never been supposed, since the adoption of the Constitution, that the business of the butcher, or the baker, the tailor, the wood chopper, the mining operator or the miner was clothed with such a public interest that the price of his product or his wages could be fixed by state regulation. It is true that in the days of the early common law an omnipotent Parliament did regulate prices and wages as it chose, and occasionally a colonial legislature sought to exercise the same power; but nowadays one does not devote one's property ar business to the public use or clothe it with a public interest merely because one makes commodities for, and sells, to, the public in the common callings of which those above mentioned are instances.' " 
or the time-sale or charge account add-on to the cash price were required to be trans lated into terms of interest and then measured by fixed statutory standards similar to those in effect with respect to money-loans.

The Legislature of the State of North Dakota recently attempted to enact a regulatory statute for the "protection" of instalment-buyers. ${ }^{31}$ The Supreme Court of the State gave the statute a construction which made it applicable only to loans disguised as sales. The opinion of the Court shows clearly, however, what the decision would have been, except for the saving construction which it applied,namely that the law would be unconstitutional as a "price-fixing statute." The opinion of the Court is illuminating on the subject of the possibilities of such legislative intervention. ${ }^{32}$

The types of commodities which are regularly sold on credit are myriad; the selling terms vary with the commodity; variations in the financing plans which may be made available for different commodities sold on credit are frequent; the elements of cost, expense, and other overhead items and of course the element of risk are highly variable in their nature. To entrust to a legislative body the responsibility for determining the extent to which these varying factors should be reflected in the creditprice of every commodity sold on instalment terms would result in the interposition of government in business to an extent never before conceived of, even in these days

"Saylor v. Brady, 63 N. D. $47 x, 248$ N. W. 673 (r933). The North Dakota usury statute, N. D. Laws I933, c. I40, provided: "No person, co-partnership, association, or corporation shall directly or indirectly take or receive, or agree to take or receive, in money, goods or things in action, or in any other way, any greater sum or any greater value for the loan or forbearance of money, goods or things in action, than eight per cent per annum, and in the computation of interest, the same shall not be compounded. Any violation of this Section shall be deemed usury; provided, that any contract hereafter made, to pay interest on interest overdue shall be deemed usury; provided further, that any evasion of this act by charging more for goods or chattels when sold on credit, or an deferred payments, or when sold under monthly or installment payments, shall be deemed usury whenever the total payments shall exceed she cash selling price, plus eight per cent interest. Nothing in this act shall be construed by any court to excuse or legalize any past evasion of the usury law, or exonerate any person, firm or corporation that may have been guilty in the past of charging a usurious rate of interest, in violation of Section 6073 of the Supplement to the Igr3 Compiled Laws of North Dakota, as amended by Chapter 274, Session Laws, I927."

${ }^{32}$ The Court said (id. at $476,248 \mathrm{~N}$. W. at 675): "After reading the statute carefully and having in mind the consequences inevitably attendant upon any other construction, we are forced to the conclusion that the Legislature did not by this amendment enact a price-fixing statute or forbid or penalize sales of personal property on credit or on deferred or installment payments at different and higher prices than those at which such property would have been sold for cash. . . . The end at which the amendment statute aims is not the prevention of sales of the sorts enumerated, but the evasion of the prohibition of excessive interest through the device of such sales. If, as plaintiff contends, the purpose of the proviso be to prohibit the sale of such property on time at a price greater than tire cash price, plus 8 per cent interest on the deferred payments, though there be no intent to evade the usury prohibition, the effect is most extraordinary and far-reaching. No farmer can sell grain or a horse or a thoroughbred bull on time, nor a hardware man a washing machine, nor a machine dealer a plow, nor a wholesale grocer to a retailer, nor any of them offer a discount for cash in thirty, sixty, or ninety days, where the time price is greater than the cash price plus interest at the rate of 8 per cent per annum on the deferred payments. And such instances can be multiplied without end. So it seems to us in applying the amended statute attention must be given to the facts in each particular case. If the sale be made in good faith and the time price be fixed at a sum greater than the cash se!ling price for any other reason than to evade the prohibition against usury, there is no transgression of the statute and no penalties attach, even though the difference be greater than the interest reckoned at 8 per cent on the deferred payments." 
of advanced social and economic philosophy. The State Banking Commission and Interim Advisory Legislative Committee in its Report to the Wisconsin Legislature recognizes the danger of the regulation thesis, in the following language:

"It would appear to be a stupendous, if not an impossible, task for any rate fixing authority at this time to arrive at the rates on the-various types of security when the different lengths of time and the different balances are taken into consideration.... Furthermore, the Committee feels that there are reasons in requiring a maximum rate on cash loans which do not exist under merchandise installment credit. In a great many instances, cash loans are predicated upon emergencies which are so urgent that the borrower will make almost any sacrifice to make a loan. This makes him an especially easy subject for exploitation." 33

It is also significant that Dr. William T. Foster, Director of the Pollak Foundation for Economic Research which has reported the existence of a great many abusive practices in the field of instalment selling and instalment sales financing is definitely opposed to any form of statutory fixing of financing charges. ${ }^{34}$

An examination of the footnote references appended to Mr. Berger's treatise discloses that the sources of Mr. Berger's factual information have been largely confined to writings and reports of those whose evident purpose it was to ascertain and report upon the abuses existing in the field of instalment selling and instalment sales financing, rather than to weigh, by a thorough-going study of the entire subject matter, the benefits which have been derived from the wise extension of consumer credit and consumer credit financing against the occasional abuses of a small minority of those operating in this field. The writer of this Commentary is convinced that Mr. Berger's approach and his conclusions would have been entirely different if there had been made available to him the background of facts which the writer has attempted to set forth in this Commentary.

${ }^{23}$ At p. 59.

${ }^{34}$ An unqualified statement to this effect was made by Dr. Foster before the Joint Committee on Banks and Banking of the Senate and House of Representatives of the Commonwealth of Massachusetts at a public hearing (at which the writer of this Commentary was present) on various proposed legislative measures relating to the field of consumer credit. See also Foster and Foster, Rate Aspects of Instalment Legislation, infra, p. 198. The Consumers Advisory Board has taken the same position as Dr. Foster. Id. at p. 193 . 